\title{
Hysteroscopic treatment of Asherman's Syndrome
}

\section{Asherman Sendromu'nun Histereskopik Tedavisi}

\author{
Coşkun Simsirr, Buğra Coşkun, Bora Coşkun, Turgut Var, Müiberra Namlı Kalem
}

Liv Hospital Ankara, Department of Obstetric and Gynecology, Ankara, Turkey

Corresponding author: Müberra Namlı Kalem, MD, Liv Hospital Ankara, Department of Obstetric and Gynecology, Ankara, Turkey

E-mail: muberranamli@ hotmail.com

Received/Accepted: June 18, 2019,/June 29, 2019

Conflict of interest: There is not a conflict of interest.

\section{SUMMARY}

Objective: To assess the achievement of hysteroscopic treatment for Asherman's Syndrome(AS), also called 'intrauterine adhesions(IUAs) or Intrauterine synechiae'.

Method: Retrospectively,27 patients with AS were enrolled in our study at Ankara liv hospital between 2017-2019. These patients were evaluated with hysteroscopically then they had adhesiolysis at the same session. The monopolar knife was used for adhesiolysis and the operation was gone on until adequate cavity enlargement was achieved. Intrauterine device (IUD) was placed in the new occurred cavity, and combined hormonal therapy(high dose estrogen and progesterone) was given for two months. American Fertility Society classification was used for scoring of IUAs. After IUD was taken out, they were called, and their menstrual pattern and fertility status were learned. If their symptoms recurred they were hysteroscopically evaluated again.

Results: 27 patients were hysteroscopically diagnosed as AS. 15of them had reproductive problems, and other 12 patients had an only menstrual abnormality. Thirteen patients had pregnancy-related curettage; four patients had dilatation and curettage(D\&C) for their menstrual problems. After hysteroscopic treatment, 6 of 12 patients with only menstrual abnormality had a normal menstrual pattern, 2 of them did not have a normal period but a little bit better(from amenorrhoea to hypomenorrhea). 8 of 15 infertile patients had positive pregnancy test(live born:6, spontaneous abortion:2). And also, all these pregnant women were seconder infertile patients.

Conclusions: Hysteroscopy is the most useful technique for diagnosis and treatment for Asherman's Syndrome. And also, the hysteroscopic procedure has a positive effect on pregnancy rate and menstrual regularity. Keywords: Asherman's Syndrome, intrauterine adhesions, hysteroscopic treatment

\author{
Coskun Simsir \\ (D) Buğra Coşkun \\ (D) Bora Coşkun \\ (D) Turgut Var \\ (iD) Müberra Namlı Kalem
}

ORCID IDs of the authors: C.S. 0000-0003-1825-6584 B.C. $0000-0003-1938-3833$ B.C. 0000-0002-2338-7186 T.V. 0000-0002-4479-1399 M.N.K. 0000-0002-2316-5495 
Amaç: "İntrauterin adezyon (IUA)" veya "Intrauterin sineşi "olarak da adlandırılan Asherman Sendromu (AS) için histeroskopik tedavinin başarısını değerlendirmek.

Yöntem: 2017-2019 yılları arasında Ankara Liv Hospital'deki AS'li 27 hasta retrospektif olarak değerlendirildi. Hastalara histeroskopi sonrası aynı seansta monopolar sistem ile adeziyoliz uygulandı. Yeterli kavite sağlandıktan sonra yeni oluşan kaviteye intrauterin cihaz (RİA) yerleştirildi ve iki ay boyunca kombine hormonal tedavi (yüksek doz östrojen ve progesteron) verildi. IUA'ların derecelendirilmesi için American Fertility Society sınıflandırması kullanıldı. RİA çıkarılması sonrası hastalar tekrar değerlendirilerek adet düzenleri ve doğurganlık durumları öğrenildi. Eğer semptomları tekrarladiysa, tekrar histeroskopi uyguland1.

Bulgular: Histeroskopik olarak AS tanısı alan 27 hastadan 15 tanesinde üreme sorunu, diğer 12'sinde sadece menstrüel anomali vardı. Histeroskopik tedavi sonrası, sadece menstrüel anormalliği olan 12 hastanın 6'sında normal adet, ikisinde de normal olmasa bile iyiye gidiş (amenore'den hipomenore) izlendi. Tedavi sonrası infertil hastaların 8'inde gebelik elde edildi (canlı doğum: 6, spontan abort: 2). Gebelik elde edilen tüm hastalar sekonder infertil gruptaydı.

Sonuç: Histeroskopi, Asherman Sendromu tanı ve tedavisi için en faydalı tekniktir. Ayrıca, histeroskopik prosedürün hamilelik oranları ve adet düzeni üzerine olumlu etkileri vardır.

Anahtar sözcükler: Asherman Sendromu, intrauterin adezyon, histeroskopik tedavi

\section{INTRODUCTION}

Intrauterine adhesions are first reported in 1894 by Heinrich Fritsch ${ }^{1}$ and further described by Asherman in $1948^{2-3}$. In these articles, the disease is described as a primary uterine disease, often presenting secondary amenorrhea because of trauma to the recently pregnant uterus, especially after D\&C. By the time etiology, symptomatology, pathology, and treatment of AS are evolved. Currently, AS is defined as 'partial or complete obliteration of the uterine cavity by adhesions with resulting menstrual abnormalities, infertility, or recurrent pregnancy loss.' Although most cases are associated with trauma to basalis layer of endometrium from surgical procedures such as $\mathrm{C} \& \mathrm{~S}$, myomectomy, hysterotomy, D\&C, manual removal of the placenta, non traumatic factors can be also related with AS like postabortal endometritis ${ }^{4}$, puerperal sepsis ${ }^{5}$, particular infections such as tuberculosis endometritis, caustic abortifacients and even normal delivery ${ }^{6}$. Postpartum curettage is the most devastating one.

Hooker et al. reported that the incidence of intrauterine adhesions after one D\&C was found $16 \%$ and most of them were in the mild stage. After two and three procedures, the incidences were $14 \%$ and $32 \%$ respectively ${ }^{7}$. When the carriage is done during $2^{\text {nd }}, 3^{\text {rd }}, 4^{\text {th }}$ postpartum week, risk of IUA gets higher. The endometrium may be more susceptible to trauma, especially the basalis layer in this period. Regardless of whatever reason, the prognosis of AS is poor. The symptomology is also now known to range from normal menstruation, through hypomenorrhea, to amenorrhea $^{8}$, infertility and obstetrics complications'. Patients with amenorrhea and cyclic pain can be associated with hematometria. In the presence of adhesions incidence of pregnancy-related abnormalities are higher than normal, like ectopic pregnancy, recurrent miscarriage, premature labor, and abnormal placentation ${ }^{8}$.

Pathology shows fibrous connective tissue with or without glandular tissue; this can be ranged from firm to dense. Treatment is always surgical and aims to restore the uterine cavity and prevent recurrent adhesions. Hysteroscopic lysis of adhesions is the main method of treatment of AS. Other treatments must be performed after hysteroscopy has failed. Most authors use an intrauterine device and high dose combined hormonal treatment(estrogen and progesterone) after hysteroscopic adhesiolysis. Treatment's outcomes are difficult to evaluate as there are no universally agreed on the classification system of AS. There is two familiar classification system for AS; American Fertility Society's (AFS) classification (Table 1) and European classification. AFS also includes the menstrual pattern. AS can cause abnormal placental implantation and subsequent blood loss, transfusion, and hysterectomy. The complications of the hysteroscopic procedure are, like other many surgical procedures, infection, bleeding, and uterine perforation. We reported our experience in the use of operative hysteroscopy at our hospital. This study aims to retrospectively evaluate the safety and efficacy of hysteroscopic adhesiolysis by observing re-establishment of the uterine cavity, postoperative resumption of menses, pregnancy rate, and outcomes. 
Table 1: Intrauterine Adhesions Classification/American Fertility Society, 1998.

\begin{tabular}{|l|c|c|c|}
\hline The extent of Cavity involved & $<1 / 3$ & $1 / 3-2 / 3$ & $>2 / 3$ \\
\hline Score & 1 & 2 & 4 \\
\hline Type of Adhesions & Firmly & Firmly\&Dense & Dense \\
\hline Score & 1 & 2 & 4 \\
\hline Menstrual Pattern & Normal & Hypomenore & Amenore \\
\hline Score & 1 & 2 & 4 \\
\hline Stage 1 & Mild & $1-4$ & \\
Stage 2 & Moderate & $5-8$ & \\
Stage 3 & Severe & $9-12$ & \\
\hline
\end{tabular}

\section{MATERIAL AND METHODS}

In Ankara liv hospital between 2017-2019, 27 patients were diagnosed with AS via hysterosalpingography(HSG). Demographic data were collected via a retrospective chart review, including patient age, pregnancy history, presenting symptoms, menstrual characteristics, past procedures, and subsequent outcomes when available.

Under general anesthesia and sterile conditions, all cases were hysteroscopically scored according to AFS Classification. (Table 1). The procedure was done in the early proliferative phase of the menstrual cycle in the patients who were menstruating. Prophylactic antibiotics cefamezine at the dose of 2 gr intravenous, were given routinely at the induction of anesthesia. $10 \mathrm{~mm}$ rigid hysteroscope equipped with a hysteroscopic monopolar hook knife used for electrodissection was introduced into the cavity, obtained after prudent cervical dilatation by the Hegar's dilatators. Glycine was used as a distending medium. The procedure was stopped after adhesiolysis, and enough uterine cavity was achieved.

Simultaneously diagnostic laparoscopy was performed for patients who were infertile to detect if any other factor exists contribution to infertility. IUD (multi-load copper T) was inserted into the uterine cavity, and high dose combined hormonal therapy (estrogen and progesterone) was given to all patients for two months. At the end of the two months after IUD were taken out, the patients who had still menstrual abnormalities were evaluated again via outpatient hysteroscopy without anesthesia. Subsequent fertility was learned by calling all patients by the phone. The follow-up was defined as immediately after treatment for women who were trying for pregnancy.

\section{RESULTS}

Twenty-seven patients were hysteroscopically diagnosed asAS. The median age was 31 years (range 21-39).

15 of them had reproductive problems, and other 12 patients had only menstrual abnormality (Table 2). Twelve patients had only menstrual abnormalities. Eight of them had amenorrhea, four of them had hypomenorrhea. Fifteen patients had reproductive problems. Six of them were primer infertile, nine of them were seconder infertile. Three patients of secondary infertile had habitual abortus.

Table 2: Characteristics and post-treatment status according to clinical presentations

\begin{tabular}{|c|c|c|c|}
\hline $\begin{array}{c}\text { Clinic } \\
\text { Presentation }\end{array}$ & $\begin{array}{c}\text { Duration } \\
\text { Mean (min-max })\end{array}$ & Subclinical Form & $\begin{array}{c}\text { Clinic after hysteroscopic } \\
\text { treatment }\end{array}$ \\
\hline $\begin{array}{c}\text { Menstrual } \\
\text { abnormality } \\
(\mathrm{n}=12)\end{array}$ & $\begin{array}{c}1,65 \text { years } \\
(4 \text { months-5years })\end{array}$ & $\begin{array}{c}\text { Amenorrhea } \\
(\mathrm{n}=8)\end{array}$ & $\begin{array}{c}6 \text { patients: normal mensturation, } \\
2 \text { patients: a little bit better }\end{array}$ \\
\cline { 3 - 4 } & & $\begin{array}{c}\text { Hypomenorrhea } \\
(\mathrm{n}=4)\end{array}$ & No change \\
\hline $\begin{array}{c}\text { Reproductive } \\
\text { problems } \\
(\mathrm{n}=15)\end{array}$ & $\begin{array}{c}6,2 \text { years } \\
(1-17 \text { years })\end{array}$ & $\begin{array}{c}\text { primer infertile } \\
(\mathrm{n}=6)\end{array}$ & No pregnancy \\
\cline { 3 - 4 } & & $\begin{array}{c}\text { seconder infertile } \\
(\mathrm{n}=9)\end{array}$ & No pregnancy \\
\cline { 3 - 4 } & & & No pregnancy \\
\hline
\end{tabular}


In the obstetric histories; $48 \%$ (n: 13) patients had endometrial trauma on the gravid uterus. $15 \%$ (n: 4) patients had elective D\&C, 37\% (n: 10) had pregnancy-related curettage (incomplete abortus and intrauterine exitus at first trimester). Four patients out of 10 had D\&C after postpartum placental retention. One patient had three times
D\&C because of molar pregnancy. One patient underwent $C \& S$ after uterine rupture. One patient had hysterotomy due to intrauterine exitus of 18 weeks gestational age. Only one patient had D\&C for menometrorrhagia, two patients had only C\&S. (Table 3)

Table 3: Characteristics of AS patients undergoing hysteroscopy and number of cases due to Obstetric histories

\begin{tabular}{|c|c|c|}
\hline $\begin{array}{c}\text { Age } \\
\text { Mean (min-max) }\end{array}$ & \multicolumn{2}{|r|}{31 years $(21-39)$} \\
\hline \multirow{3}{*}{$\begin{array}{l}\text { Stage of AS according } \\
\text { to AFS classification at } \\
\text { initial surgical } \\
\text { adhesiolysis }\end{array}$} & & $\begin{array}{c}\text { Mild } \\
(\mathrm{n}=6,22 \%)\end{array}$ \\
\hline & & $\begin{array}{c}\text { Moderate } \\
(\mathrm{n}=13,48 \%)\end{array}$ \\
\hline & & $\begin{array}{c}\text { Severe } \\
(\mathrm{n}=8,30 \%)\end{array}$ \\
\hline \multirow{8}{*}{$\begin{array}{l}\text { Obstetric histories } \\
\qquad(\mathrm{n}=27)\end{array}$} & \multicolumn{2}{|c|}{$\begin{array}{l}\text { Endometrial trauma on the gravid uterus } \\
(\mathrm{n}=13)\end{array}$} \\
\hline & \multicolumn{2}{|c|}{$\begin{array}{l}\text { Elective D\&C } \\
(\mathrm{n}=4)\end{array}$} \\
\hline & \multirow{6}{*}{$\begin{array}{l}\text { Pregnancy related } \\
\text { curettage } \\
(n=10)\end{array}$} & $\begin{array}{l}\text { D\&C after postpartum placental retention } \\
\qquad(\mathrm{n}=4)\end{array}$ \\
\hline & & $\begin{array}{l}\text { Three times D\&C because of molar } \\
\text { pregnancy } \\
(\mathrm{n}=1)\end{array}$ \\
\hline & & $\begin{array}{l}\text { Underwent } \mathrm{C} \& \mathrm{~S} \text { after uterine rupture } \\
\qquad(\mathrm{n}=1)\end{array}$ \\
\hline & & $\begin{array}{l}\text { Hysterotomy due to intrauterine exitus of } 18 \\
\text { weeks gestational age } \\
\qquad(\mathrm{n}=1)\end{array}$ \\
\hline & & $\begin{array}{c}\text { D\&C for menometrorrhagia } \\
(\mathrm{n}=1)\end{array}$ \\
\hline & & $\begin{array}{c}\text { Only C\&S. } \\
(\mathrm{n}=1)\end{array}$ \\
\hline
\end{tabular}

Mean infertility duration was 6,2years (1-17 years) and mean duration of menstrual problems was 1,65 years( 4 months-5 years). The delay between the causal procedure and hysteroscopic treatment of IUA was unfortunately not available.

At initial surgical adhesiolysis, 22\% (6/27) were diagnosed with mild stage, $48 \%$ (13/27) with moderate stage and $30 \%(8 / 27)$ with severe stage according to AFS classification of AS.

After hysteroscopic treatment, 6 of 12 patients with only menstrual abnormality had a normal menstrual pattern, 2 of them did not have a normal period but a little bit better(from amenorrhoea to hypomenorrhea). Totally, 67\%(8/12) patients were satisfied with the treatment, all of these eight patients from the amenorrheic group.

After treatment, Only eight patients out of 15 (53\%) were pregnant, and all of them were secondary infertile patients. Among eight patients, six of them were delivered with live-born children. One of them was preterm delivery, And two patients had a spontaneous abortion. We observed no ectopic pregnancy. There was no any placental implantation anomaly in our series.

A complication was noted only two patients out of $27(7 \%)$ involving a perforation. One of them occurred during cervical dilatation, and another one was occurred during the hysteroscopy procedure, from the uterine fundus. The procedure 
was stopped, and immediately defects were repaired via laparoscopy. No other complication was noted in our series. At the end of the two months after IUD were taken out, the patients who had still menstrual abnormalities were evaluated again via outpatient hysteroscopy without anesthesia. So four patients had two hysteroscopic sessions, and also one patient had three sessions.

\section{DISCUSSION}

Intrauterine adhesions, AS is one of the popular challenges for gynecologists. It can be confronted with very different and complicated clinical presentations; menstrual abnormalities, infertility, pregnancy complications, cyclic abdominal pain. However, we can classify these different symptoms into two categories: reproductive problems and menstrual disorders. The major risk factor for the AS is uterine trauma, especially associated with the post-pregnancy state, possibly related to hormonal changes at that time.

The treatment of uterine synechiae has largely benefited from technological progress in endoscopic surgery. Operative hysteroscopy must now be first performed in all cases of intrauterine adhesions. Scissors are the best instrument when the passage of the hysteroscope alone is insufficient. This method allows the use of a smaller operative sheath, which is important in cases where even dilating the cervix, can result in a false passage. Nd-YAG laser or electrosurgical energy could also be used, but these modalities pose a risk of endometrial destruction which would seem undesirable. Even though posttreatment adhesions may be unlikely most authors use adjunctive therapy. One of the most used modalities is hormonal therapy and IUDs. When estrogen encourages endometrial growth, IUD could prevent reformation of adhesions and, hopefully, on removal result in the breakdown of any new adhesions that had formed. The dangers of the device are minimal as infection probably occurs at the time of insertion if it does occur or as a result of sexually transmitted disease.

Treatments outcomes are difficult to assess as there are no universally agreed upon classification system. However, intrauterine pregnancies rate ranges from 22 to $45 \%$ and live births range from 28 to $32 \%$. The risk of complications for those that achieve pregnancy is significant with a significant risk for placenta accrete and subsequent blood loss, transfusion, and hysterectomy.

Complications from pregnancy-related curettage are the most common cause of intrauterine adhesions. In our series, $37 \%$ of the cases had a history for pregnancy-related curettage. In a series of 1858 cases, Schenker finds a history of trauma on a gravid uterus in $90.8 \%^{8}$; A study finds $30 \%$ of synechiae after requested legal abortions $1^{0}$. Hooker published a systematic review ${ }^{7}$ : Hysteroscopy was performed at 4-6 weeks after curettage for first trimester abortion in 147 patients; in 28 patients (19\%), one or more synechiae were found, the incidence of adhesions following only one abortion was 16,3\%, 14\% after two abortions and $32 \%$ after three or more abortions ${ }^{7}$. Cesarean section is exceptionally involved: $2,8 \%$ for Rochet ${ }^{11}$ and $2 \%$ for Schenker 8. Postpartum curettage is especially dangerous. According to Butram ${ }^{12}$ and Parent ${ }^{13}$, post-partum curettage is traumatizing between the 1 st and $4^{\text {th }}$ week following delivery. The risk of adhesion is evaluated at approximately $25 \%$ 11, 13 . Synechiae may be the cause of infertility; in fact, it is often associated with other genital lesions such as a tubal pathology, uterine malformation or sperm abnormality in a partner. In our series, the most confounding factor was tubal pathology. Consequently, a genital check-up of the infertile couple is necessary before starting a therapeutic procedure. Abnormal placentation is exceptional; Although Schenker finds two placentas previa $(0,1 \%)$ and 22 accurate $(1 \%)$ out of 2151 cases $^{8}$, we have no any abnormal placentation in our series.

In our series, we note no infection or hemorrhage, but two uterine perforations occurred and were immediately diagnosed and repaired in the operation room at the same session. In case of severe adhesions, we performed an abdominal ultrasound control during hysteroscopy. Some authors recommend a simultaneous laparoscopy to minimize the risk of perforation; we think that systematic laparoscopy is not necessary and not that preventive. Good anatomical results are usually obtained. The hysteroscopic procedure is not aggressive and is sensitive to the surrounding endometrium, which is essential for a good anatomical and functional result. But also, Rochet ${ }^{11}$ reported $72 \%$ positive results by several nonhysteroscopic techniques, controlled by hysterography at 3-6 months after surgery. Some authors obtained $77.6 \%$ positive results only by the lysis techniques ${ }^{10}$. Hamou reports a success rate of $63,8 \%$ during the first sessions ${ }^{14}$. March and Israel ${ }^{15}$ had a success rate of $97 \%$.

Valle and Sciarra find a recurrence in $48,9 \%$ the cases of severe adhesions, $21,6 \%$ for moderate but none for mild synechiae. After several treatments, the recurrence rate reached $35 \%$ for severe 
synechiae and $5,2 \%$ for the moderate ones ${ }^{16}$. Results of menstrual abnormalities are good: we get a significant improvement to symptomatology in $67 \%$ of the patients, especially in amenorrhea (80\%). In 1250 and 775 cases, respectively, Schenker ${ }^{8}$ and Siegler ${ }^{17}$ note $84 \%$ and $87,2 \%$ positive results. Some authors obtain a $100 \%$ success rate for amenorrhea and hypomenorrhea ${ }^{18}$. The results are correlated to the initial gravity of the lesions. The results of reproductive problems are still disappointing. They depend on the gravity of the disease but also additional infertility factors (uterine malformation, tubal sterility, sperm abnormalities). A good anatomical result is necessary, but not always sufficient. Most of the authors globally find disappointing results on reproductive problems, even if there is a relative disparity between the series. Only, Israel reports more optimistic series about exclusively corporeal synechiae ${ }^{15}$.

Flexible plastic candles are used for curettage to minimize endometrial trauma, but still, Asherman Syndrome is a serious problem that we are dealing with it. Aim of treatment is to gain enough endometrial function and cavity after the success rate is lower than expected. Variety factors affect the success rate of treatment such as adhesion consistency and extensity, using IUD with or without hormonal therapy after the procedure, other fertility factors. Density and extensity of adhesions are important to expect the prognosis of the procedure. If the lesions are dense and highly fibrotic, they consist of massive scar tissue and no functional endometrial layer. The prognosis after curettage between second and fourth week of postpartum is also poor. Our hospital is a tertiary center, so mostly of our patients are more complicated than the normal population. This can be one of the causes of our unsatisfactory results.

Many authors support the concept of using IUD in the prevention of IUA. For this purpose, we used copper T 280 after adhesiolysis. We know that copper-bearing IUDs are not successful, because they have small surfaces and copper by itself can increase inflammatory reaction that can aggravate adhesion. For this purpose loop, IUD is the best choice, but in our country, there is no loop IUD. So we had to use copper T 280 , which is a little more surface than copper T380A. In some studies, a Foley catheter with a three cc balloon was used for 15 days. Although the pregnancy rate was greater than the control group, infection rate, and also the pressure of the balloon on endometrium can increase adhesion formation after application.
In this study, a standardized pathway used for the operative and postoperative procedures to all patients. This is the major strength of our study. Also, another strength of our study is the longterm follow-up of the patients included in the study after hysteroscopic treatment. The most important limitation of our study is the retrospective nature of the study. The low number of subjects is also an important limitation.

\section{CONCLUSION}

Operative hysteroscopy is the best method to diagnose, classify, treat, and follow-up patients with IUA. Hysteroscopy must be the first choice in all cases with AS. Although a good anatomical result and the resumption of normal menstrual periods can be expected, the reproductive outcome is still disappointing. Restoration of a normal cavity and regular menstruation is not inevitably followed by normal fertility. Improvement of these results will depend on better management of additional infertility factors, early diagnosis, and treatment of initial lesions and their recurrences. But prevention is the best therapy by reducing uterine trauma as much as possible, particularly on a gravid uterus.

Prospective controlled studies are needed to determine the best diagnostic and treatment method of AS. The management of disease still poses a challenge. Close antenatal follow-up is necessary for women who conceive after treatment. It will be difficult to truly evaluate the usefulness of adjunctive measures until multicenter reports of successful treatments become available.

\section{REFERENCES}

1. Fritsch H. Ein Fall von vlligem Schwaund der Gebormutterhohle nach Auskratzung. Zentralbl Gynaekol 1894; 18:1337-1342.

2. Asherman JG. Amenorrhoea is traumatic. J Obstet Gynecol Br Emp 1948; 55:23.

3. Asherman JG. Traumatic inta-uterine adhesions. J Obstet Gynecol Br Emp 1950; 57:892.

4. Satwik R. Asherman's Syndrome and Hysteroscopy. Manual of Fertility Enhancing Hysteroscopy: Springer; 2018. p. 111-35.

5. Liu L, Yang H, Guo Y, Yang G, Chen Y. The impact of chronic endometritis on endometrial fibrosis and reproductive prognosis in patients with moderate and severe intrauterine adhesions: a 
prospective cohort study. Fertility and sterility. 2019.

6. Chen Y, Liu L, Luo Y, Chen M, Huan Y, Fang R. Prevalence and impact of chronic endometritis in patients with intrauterine adhesions: a prospective cohort study. Journal of minimally invasive gynecology. 2017;24(1):74-9.

7. Hooker A, Fraenk D, Brölmann H, Huirne J. Prevalence of intrauterine adhesions after termination of pregnancy: a systematic review. The European Journal of Contraception \& Reproductive Health Care. 2016;21(4):329-35.

8. J.G Schenker and E.J Margalioth, Intrauterine adhesions; an update appraisal. Fertile Steril 37 (1982), pp. 593-610. View record in Scopus/ Cited By in Scopus (65).

9. 9 ) Galamb A, Pethő B, Fekete D, Petranyi G, Pajor A. Uterine anomalies in women with recurrent pregnancy loss. Orvosi hetilap. 2015;156(27):1081-4.

10. Dreisler E, Kjer JJ. Asherman's syndrome: current perspectives on diagnosis and management. International journal of women's health. 2019;11:191-8.

11. Rochet Y, Dargent D, Bremond A, Priou G, Rodrigoz RC. Le denevir obstetrical des femmes operes de synechies uterines. J Gynecol Obstet Biol Reprod 1979;8: 723-726.
12. Butram UC, Turati G. Uterine synechiae: variation in severity and some conditions which may be conductive to severe adhesions. Int J Fertile 1977; 22: 98-103.

13. Parent B, Barbot J, Dubuisson JB. Synechies uterines. Encycl Med Chir Gynecol 1981; 140A(Suppl. 1988): 10.

14. Hamou J, Salat-Baroux J, Siegler AM. Diagnosis and treatment of intrauterine adhesions by microhysterescopy. Fertile Steril 1983;39: 321-326

15. March CM, Israel R. Gestational outcome following hysterescopic lysis of adhesions. Fertile Sterile 1981; 36:455459.

16. Malhotra N, Gupta S, Manchanda R, Malhotra J, Malhotra K, Sharma M, et al. Prevention of Adhesion Reformation After Hysteroscopic Surgery. Hysteroscopy: Springer; 2018. p. 719-24.

17. Siegler AM, Valle RF. Therapeutic hysterescopic procedures. Fertile Steril 1988; 50:685-701.

18. Barel O, Krakov A, Pansky M, Vaknin Z, Halperin R, Smorgick N. Intrauterine adhesions after hysteroscopic treatment for retained products of conception: what are the risk factors? Fertility and sterility. 2015;103(3):775-9. 